\title{
Announcement \\ The Jelliffes Foundation and Award
}

The Jelliffes Foundation and Award have been established in admiration of the great pioneering work of the late Professor Derrick B. Jelliffe and his widow E.F. Patrice Jelliffe in promoting the health and wellbeing of the world's infants and children, and in gratitude for the unfailing support and encouragement which the Jelliffes always extended to others who were trying to work for the same cause.

The purpose of the Award is to continue the Jelliffes' lifelong action by supporting young persons who are doing valuable work for the health and nutrition of infants and children, and for enabling mothers to breastfeed.

To provide a firm financial basis for the Award, a Foundation capital of about US $\$ 200,000$ will be necessary. The interest from the Foundation capital will constitute the Award which will be made annually, if possible each August during Breastfeeding Week.

The candidate receiving the Award will be selected on the basis of recommendations to the Foundation Board, of which Mrs Patrice Jelliffe will be a member, and according to criteria set by her. Other members of the Board are: Annelies Allain, IOCU; Manuel Carballo, WHO; Anwar Fazal, WABA; James Grant, UNICEF; Elisabet Helsing, WHO; Michael Latham, Cornell University and Audrey Naylor, Wellstart International.

To establish the Foundation, a Deposit Account has been opened in the Société de Banque Suisse (the bank used by WHO), which will ultimately be in the name of The Jelliffes Foundation. Provisionally the account has been opened in the name of Mrs Patrice Jelliffe and Dr Elisabet Helsing who works for the WHO Regional Office for Europe in Copenhagen. For the present both will assume personal responsibility for the account. Appropriate legal arrangements are being made to ensure proper procedures and accountability.

In the first phase, from 1 December 1992, appeals for contributions to the Foundation will be sent through various networks and channels to friends and admirers of the Jelliffes. All individuals, organizations and institutions who have benefitted from their work and support or who share their concerns and ideas are encouraged to make a donation. They will be appropriately listed as contributors to the Foundation. Further details of the Foundation and its plans can be obtained from E.F. Patrice Jelliffe, 15435 Hamner Drive, Los Angeles, California 90077, USA.

The Foundation's account is as follows: A/C D3-103, 996.0

Société de Banque Suisse

Bureau O.M.S.

Avenua Appia

1211 Geneve 27

Switzerland

Donations have to be marked: E.F. Patrice Jelliffe and Elisabet Helsing for the Jelliffes Foundation. 